\title{
Proliferative and steroidogenic capabilities of rat granulosa cells of different sizes
}

\author{
K. J. Lederer ${ }^{*}$, A. M. Luciano ${ }^{\dagger}$, A. Pappalardo and J. J. Peluso ${ }^{\ddagger}$ \\ Department of Obstetrics and Gynecology, University of Connecticut Health Center, Farmington, \\ CT 06030, USA
}

\begin{abstract}
Equine chorionic gonadotrophin stimulates both rat granulosa cell mitoses and oestradiol secretion. However, the mitotic potential of oestradiol-secreting granulosa cells is not known. In the first study, granulosa cells of different sizes were isolated and their ability to secrete oestradiol and proliferate in vitro was determined. Granulosa cells were harvested from equine chorionic gonadotrophin-primed immature rats, separated on a $15-45 \%$ Percoll gradient, and collected in 12 fractions. An enriched population of small granulosa cells $\left(44 \pm 1 \mu \mathrm{m}^{2}\right)$ was collected in fractions 3 and 4 and an enriched population of large granulosa cells $\left(97 \pm 2 \mu \mathrm{m}^{2}\right)$ in fractions $6-8$. When granulosa cells from each fraction were cultured for $24 \mathrm{~h}$ in the presence of testosterone, the large cells secreted $50 \%$ more oestradiol than did the small cells $(P<0.05)$. Aromatase was shown, by immunocytochemistry, to be expressed mainly by granulosa cells larger than $73 \mu \mathrm{m}^{2}$, with the relative amount of aromatase expressed per cell increasing with increasing cell size. However, not all large granulosa cells expressed aromatase. To test proliferative capacity, cells from each fraction were cultured with testosterone and the mitogen, insulin. This study showed that only small cells were able to undergo insulin-induced mitosis. In a second study, follicles of different sizes were isolated from immature and equine chorionic gonadotrophin-primed immature rats and the granulosa cell size distribution determined for each follicle size. This study confirmed that equine chorionic gonadotrophin altered the size distribution from principally small mitotically competent cells to large oestradiol-secreting cells. Studies in vitro further demonstrated that FSH in the presence of 8-bromo-cAMP stimulated small granulosa cells to differentiate into large cells. It is proposed that changes in the population of granulosa cells could account for both the slower growth rate of large antral follicles compared with small antral follicles and the inverse relationship between follicular oestradiol secretion and DNA synthesis of granulosa cells.
\end{abstract}

\section{Introduction}

During each menstrual or oestrous cycle, the granulosa cells of a select cohort of follicles are stimulated to undergo a series of mitoses. As these follicles grow, their capacity to synthesize and secrete oestradiol increases (Greenwald and Terranova, 1988). The two pituitary gonadotrophins, FSH and LH, are the primary inducers of follicular growth and oestradiol secretion. Both LH and FSH stimulate proliferation of granulosa cells in primary follicles, and once a follicle reaches a diameter of approximately $150 \mu \mathrm{m}, \mathrm{FSH}$ induces antrum formation and aromatase activity within the granulosa cells (Greenwald and Terranova, 1988). Throughout the course of follicular development, the gonadotrophins act to maintain aromatase activity,

*Present Address: Center for Fertility and Reproduction, Ingalls Professional Building, 71 West 156th St, Suite 208, Harvey, IL 60426, USA.

'Present Address: Instituto Sperimentale Italiano 'Lazzaro Spallanzani', Via Celoria, 2 - 20133 Milano, Italy.

${ }^{\ddagger}$ Correspondence.

Received 6 June 1994. oestradiol secretion and granulosa cell mitosis (Greenwald and Terranova, 1988).

It is important to appreciate that in the rat oestrous cycle, rapid follicular growth occurs between oestrus and dioestrus and precedes maximum oestradiol secretion (Hirshfield, 1991). This temporal separation between growth and oestradiol secretion correlates well with the observation that there is an inverse relationship between oestradiol secretion and granulosa cell DNA synthesis within follicles (Frishman et al., 1992; Monniaux, 1987). While the separation of mitogenic and steroidogenic functions is well documented, it is not known how the granulosa cells within the developing follicle perform these diverse functions. At least two possibilities could explain this phenomenon. First, there could be two types of granulosa cell. One type could be undifferentiated and only able to undergo mitosis, while a second type could express aromatase, secrete oestradiol and still be capable of mitosis. If this is the case, then oestradiol secretion should be inhibited temporarily when these aromatase-containing cells undergo mitosis (Peluso et al., 1991). An alternative possibility is that only granulosa 
cells that do not secrete oestradiol undergo mitosis and cells that do secrete oestradiol lose their mitotic potential. Neither of these two possibilities have been tested directly.

Rao et al. (1991a) developed a Percoll-based procedure that can be used to collect enriched populations of granulosa cells that do, and granulosa cells that do not, secrete oestradiol. Although Percoll separates cells on the basis of density, Rao et al. (1991a) showed that two sizes of granulosa cell can be isolated using their procedure: small non-steroidogenic granulosa cells, and larger granulosa cells that secrete both oestradiol (Rao et al., 1991a) and progesterone (Sanbuissho et al., 1993). A similar heterogeneity of granulosa cells has been observed within human follicles (Hartshorne, 1990). It is now possible to determine which of the two proposed mechanisms account for the separation of the steroidogenic and mitogenic functions during follicular maturation using this granulosa cell separation technique. In the first series of studies, granulosa cells that secreted oestradiol were separated from those that did not and the ability of each cell type to undergo mitosis in response to the known rat granulosa cell mitogen, insulin (Peluso et al., 1991; Bley et al., 1991), was determined. In addition, studies were carried out to see if the granulosa cell size distribution changes with increasing follicular size or equine chorionic gonadotrophin (eCG) treatment. A third series of studies was performed to determine whether small granulosa cells that did not secrete oestradiol could be induced to differentiate into large granulosa cells in vitro.

\section{Materials and Methods}

\section{Animals}

Immature female Wistar rats (22 days of age) were obtained from Charles River Laboratory (Wilmington, MA) and housed under controlled conditions of temperature, humidity, and photoperiod ( $12 \mathrm{~h}$ light: $12 \mathrm{~h}$ dark; lights on at 07:00 h). Unless otherwise stated, rats were injected i.p. with eCG (20 i.u. in $0.2 \mathrm{ml}$ PBS) to induce follicular growth, aromatase expression and oestradiol synthesis. Forty-eight hours later, the rats were cervically dislocated between 09:30 and 10:00 $\mathrm{h}$.

\section{Preparation of culture medium}

RPMI-1640 without phenol red (GIBCO Laboratories, Grand Island, NY) was used in all culture experiments. It was supplemented with penicillin $\left(0.14 \mathrm{~g} \mathrm{l}^{-1}\right)$, streptomycin $\left(0.27 \mathrm{~g} \mathrm{l}^{-1}\right)$ Hepes $\left(4.76 \mathrm{~g} \mathrm{l}^{-1}\right)$, BSA fraction $\mathrm{V}\left(2 \mathrm{~g} \mathrm{l}^{-1}\right)$, sodium selenite $\left(5 \mathrm{ng} \mathrm{ml}^{-1}\right)$, transferrin $\left(5 \mu \mathrm{g} \mathrm{ml}^{-1}\right)$ and sodium bicarbonate $\left(2.2 \mathrm{~g} \mathrm{I}^{-1}\right)$. The $\mathrm{pH}$ was adjusted to 7.4 and the medium filtered through a $0.2 \mu \mathrm{m}$ filter. Insulin $\left(5 \mu \mathrm{g} \mathrm{ml}^{-1}\right)$ and testosterone $\left(0.576 \mu \mathrm{g} \mathrm{ml}^{-1} ; 2 \mu \mathrm{mol}\right)$ were added to the cultures (Sigma Chemical Co., St Louis, MO) as required. Testosterone was dissolved in ethanol at a concentration of $0.576 \mathrm{mg} \mathrm{ml}^{-1}$ and then diluted in RPMI-1640 to the desired final concentration. Since insulin is a wellcharacterized mitogen of rat granulosa cell, it was added to assess the mitogenic potential of small and large granulosa cells. The medium was always supplemented with testosterone. Testosterone serves as a substrate for aromatase, thereby allowing any granulosa cell containing aromatase to synthesize oestradiol.

\section{Isolation of granulosa cells}

Granulosa cells were isolated according to the procedure of Rao et al. (1991a). Briefly, ovaries were placed in Medium 199 containing $0.2 \% \mathrm{BSA}, 9.1 \mathrm{mmol}$ EGTA $\mathrm{l}^{-1}$ at $\mathrm{pH} 7.4$. The follicles within the ovary were punctured with fine needles and then incubated for $5 \mathrm{~min}$ at $37^{\circ} \mathrm{C}$ in $5 \% \mathrm{CO}_{2}: 95 \%$ air. The ovaries were transferred to Medium 199 containing $0.2 \% \mathrm{BSA}$, $2.1 \mathrm{mmol}$ EGTA $\mathrm{l}^{-1}$ and $0.5 \mathrm{~mol}$ sucrose $\mathrm{l}^{-1}$ at $\mathrm{pH} 7.4$, and then incubated at $37^{\circ} \mathrm{C}$ in $5 \% \mathrm{CO}_{2}: 95 \%$ air for $10 \mathrm{~min}$. The ovaries were washed and resuspended in fresh Medium 199 containing $0.2 \% \mathrm{BSA}$ then pressed to release the granulosa cells. The cell suspension was centrifuged for $30 \mathrm{~s}$ at $17000 \mathrm{~g}$ and the pellet resuspended in $1 \mathrm{ml}$ of media. At this point, approximately $80-90 \%$ of the cells were disaggregated from each other. This cell suspension was then loaded onto the top of a $15-45 \%$ Percoll:Medium-199 gradient ( $8 \mathrm{ml}$ total volume). The gradient was centrifuged at $200 \mathrm{~g}$ for $5 \mathrm{~min}$ and, starting from the top, 12 fractions of $666 \mu \mathrm{l}$ each were collected. The cells in each fraction were washed and resuspended in RPMI1640. Cells were then plated in either Lab-tek 8-chamber slides (Nunc Inc., Naperville, IL) for viability assessment, morphometric analysis or aromatase localization; 24-well plates for oestradiol secretion studies; or, $35 \mathrm{~mm}$ dishes for in situ cell counting.

\section{Viability assessment}

Granulosa cells from each fraction were plated in Lab-tek slides for $2 \mathrm{~h}$ and then washed three times with PBS. The cells were stained with hydroethidine (14 $\mu \mathrm{g}$ PBS $\mathrm{ml}^{-1}$ Polysciences, Inc., Warrington, PA) for $15 \mathrm{~min}$ at room temperature in the dark. The hydroethidine solution was replaced with PBS and the cell examined under epi-fluoresence with an excitation filter of $535 \mathrm{~nm}$ and a barrier filter of $585 \mathrm{~nm}$. At these settings, the chromatin within viable cells fluoresces bright red (Bucana et al., 1986).

\section{Morphometric analysis}

Granulosa cells from each fraction were plated in Lab-tek chamber slides, incubated for $2 \mathrm{~h}$ at $37^{\circ} \mathrm{C}$ in $5 \% \mathrm{CO}_{2}: 95 \%$ air and then fixed in $10 \%$ buffered formaldehyde. The cells were stained with haematoxylin and eosin, and observed under brightfield optics at a magnification of $\times 400$. The granulosa cell image was then obtained using a Dage 72 CCD camera (Dage-MTI Inc., Michigan City, IN) and the area and diameter determined using an image analyser (Model 3000: Image Technology Corp., Deer Park, NY).

\section{Oestradiol secretion and granulosa cell fraction}

Granulosa cells from each fraction were plated in quadruplicate in 24-well plates at a density of $5 \times 10^{4}$ cells and incubated at $37^{\circ} \mathrm{C}$ in $5 \% \mathrm{CO}_{2}: 95 \%$ air in $1 \mathrm{ml}$ of RPMI-1640 supplemented with testosterone in the presence or absence of insulin. After $24 \mathrm{~h}$, the media were removed, frozen and stored at $-20^{\circ} \mathrm{C}$ until assayed for oestradiol content. These 
experiments were repeated three times. The oestradiol assay was a direct solid-phase radioimmunoassay (Diagnostic Products Corp., Los Angeles, CA). The antiserum to oestradiol cross-reacts $100 \%$ with oestradiol and $<0.001 \%$ with oestrone and several other steroids. The assay sensitivity was $5 \mathrm{pg} \mathrm{ml}^{-1}$ and the intra- and interassay coefficients of variation were $8 \%$ and $14 \%$, respectively.

\section{Aromatase localization and quantification}

Aromatase expression was determined immunocytochemically. Granulosa cells were harvested on the same day and separated into fractions. Granulosa cells from each fraction were plated in duplicate in Lab-tek chamber slides, and then incubated at $37^{\circ} \mathrm{C}$ in $5 \% \mathrm{CO}_{2}: 95 \%$ air for $2 \mathrm{~h}$. After incubation, media were removed and cells washed with PBS, fixed for $10 \mathrm{~min}$ with $10 \%$ buffered formaldehyde and then washed twice more with PBS. Cells from each fraction were then stained for aromatase expression on the same day using identical reagents, dilutions and incubation times as outlined below.

First, the fixed cells were treated with $1 \%$ Triton $X 100$ for $5 \mathrm{~min}$ and washed twice with Tris-buffered saline $(\mathrm{pH} \mathrm{7.6)}$. One duplicate culture of each granulosa cell fraction was incubated in the presence or absence of a polyclonal antibody to aromatase. The aromatase antibody was detected using the Histomark Streptavidin-HRP detection system according to the manufacturer's instructions (Kirkegaard and Perry Laboratories Inc., Gaithersburg, MD). The presence of aromatase was indicated by the presence of a reddish orange precipitate. The rabbit anti-aromatase antibody (R-10-2) was generously provided by $\mathrm{Y}$. Owasa, Medical Foundation of Buffalo (Tamura et al., 1992). It was generated against human placental $P 450$ aromatase that had been immunoaffinity purified using a monoclonal antibody to $\mathrm{P} 450$ aromatase. This procedure has been used to detect aromatase in the ovaries of several species including rats (Ishimura et al., 1989). The amount of aromatase in stained cells was estimated by image densitometry using a Dage 72 CCD camera and the density program of the Model 3000 image analyser. Non-specific staining was determined by digitizing the granulosa cell images that were stained in the absence of the primary antibody or in the presence of normal rabbit serum. The mean densities (plus 2 SDs) for these negative controls were calculated. The images of granulosa cells stained with the aromatase antibody were also digitized and densities calculated. Granulosa cells stained with primary antibody and when the aromatase staining density was greater than the mean plus 2 SD of the negative controls they were considered stained. The specific staining density was calculated by subtracting the non-specific density from the density of granulosa cells stained in the presence of the aromatase antibody. Aromatase staining was evaluated on 100 cells from each fraction. This experiment was replicated twice.

This semi-quantitative estimate of aromatase protein expression was conducted in accordance with the protocols described by Vacca-Galloway (1985). These require the primary antibody to be used at a dilution that (i) does not maximally stain the cells and (ii) produces different staining densities in cells within and between experimental treatment groups. Our pilot studies confirm that staining done at a 1:300 dilution of rabbit anti-aromatase antibody meets this criteria.

The amount of aromatase protein was expressed in density units. These units were obtained using the density program of the Model 3000 image analyser. In this program the integrated density of an entire cell was calculated using the following equation:

$$
\text { Density (in absorbance units) }=-\sum_{i=1}^{n} \log _{10}\left(l_{i} / l_{o i}\right) \wedge A_{i}
$$

where $l_{i}$ is the light level at each pixel within the image; $l_{o i}$ is the background light level at each pixel; $n$ is the total number of all pixels in the image; $A_{i}$ is the area of each image pixel, which was set at 1 . Note that light level is given as a grey level within a range 0 to 255 and is proportional to the light intensity. To ensure repeatable absorbance readings between experimental groups and experiments, density readings were taken from a standard slide and a density reading of 40 absorbance units obtained before taking any experimental readings.

\section{Granulosa cell proliferation assessed by in situ cell counting}

The capacity of granulosa cells to undergo mitosis was assessed by adding $2-3 \times 10^{5}$ granulosa cells to $35 \mathrm{~mm}$ dishes in $1 \mathrm{ml}$ of RPMI-1640 that contained testosterone. In the first experiment, granulosa cells from fractions 3, 5, 7 and 9 were used. The second granulosa cell proliferation study used small granulosa cells, pooled from fractions 3 and 4 , and large granulosa cells, pooled from fractions $6-8$. In both studies, all unattached granulosa cells were removed after $2 \mathrm{~h}$ by replacing the media with fresh media containing insulin. The number of granulosa cells, observed within five different $160 \mu \mathrm{m}^{2}$ grids within the $35 \mathrm{~mm}$ dish, was recorded. Each grid was divided into 100 squares which allowed for the precise location of each granulosa cell. The exact location within the grid and the size of each granulosa cell was recorded onto data sheets. The grids were located at the ends of the horizontal and vertical axes and at the centre of the dish. At this plating density, 20-30 cells per grid were generally observed. After $24 \mathrm{~h}$ of culture, the number of granulosa cells present and their location in each grid was compared with the $2 \mathrm{~h}$ control values. Cell proliferation was expressed as the percentage increase in cell number over $2 \mathrm{~h}$ control value. For each experiment, 100-150 granulosa cells were observed. Each of these experiments was replicated two to three times.

The results obtained by counting cells in situ were similar to those obtained by harvesting the cells and counting them in a haemocytometer (Peluso et al., 1993). The advantages of counting the cells in situ are that it is fast, easy, eliminates cell harvesting and allows for the determination of the size of granulosa cell that undergoes mitosis. One potential disadvantage, however, is that cells that do not attach to the culture dish within $2 \mathrm{~h}$ are lost. These cells may have mitotic potential. It is estimated that $\approx 80 \%$ of the granulosa cells attach within $2 \mathrm{~h}$ (J. Peluso, unpublished). However, the viability of the non-attached granulosa cells is poor ( $\leq 5 \%$ for small granulosa cells and $\approx 40 \%$ for large granulosa cells). The non-attached large granulosa cells do not undergo mitosis if exposed to insulin (J. Peluso, unpublished). 
A second potential problem is that granulosa cells could migrate over the course of the culture period. If this occurs, it would invalidate the in situ counting procedure. We do not believe this contributes to the insulin-induced increase because the variation in the cell numbers is rather small and constant. If cells were moving from one site to another, this would result in large increases in some grids and large decreases in others. As a result the standard errors would be very large, but this is not the case. Studies in which the location of each cell within a grid was recorded at 2 and $24 \mathrm{~h}$ of culture demonstrate that $\geq 95 \%$ of all cells observed at $2 \mathrm{~h}$ are in nearly the same place $22 \mathrm{~h}$ later. In addition, granulosa cells not exposed to insulin do not increase in number, indicating a true mitogenic effect of insulin (see Fig. 5). These findings validate the use of in situ cell counting to assess cell proliferation.

\section{Follicular development and changes in the granulosa cell size distribution}

Follicles from immature and eCG-primed rat ovaries were isolated using the enzymatic digestion and dispersion procedure of Roy and Greenwald (1988) to determine whether the granulosa cell population changes with follicular growth. Immature ( 22 days of age) or eCG-treated rats were killed by cervical dislocation and the ovaries quickly removed, trimmed of fat and cut into two to four pieces. The ovarian fragments were placed in a prewarmed enzyme solution (collagenase, DNase, pronase) in a Dubnoff metabolic shaker at $37^{\circ} \mathrm{C}$ for 30 min. Subsequently, 1\% BSA in Medium 199 was added to stop the reaction and the dispersion of follicles completed by gentle mechanical agitation with a Pasteur pipette. Follicles were separated by filtering them through a series of stainless steel grids with pore sizes of 380, 280, 190, 140 and $73 \mu \mathrm{m}$, respectively (Sigma Chemical Co., St Louis, MO). The follicles were then suspended in Medium 199 containing $0.2 \%$ BSA, $5 \mathrm{mmol} \mathrm{EGTA}^{-1}$ and centrifuged at $200 \mathrm{~g}$ for $5 \mathrm{~min}$ at $4^{\circ} \mathrm{C}$. The supernatant was discarded, the follicles resuspended in fresh culture medium and the granulosa cells released. The area of 100 granulosa cells from each follicle size was determined as previously described. This experiment was repeated twice.

\section{Effect of FSH and 8-bromo-cAMP on granulosa cell area in vitro}

Lab-tek slides were coated with ProNectin F, a polymer incorporating multiple copies of RGD (arginine-glycineaspartic acid) cell attachment ligand, according to the manufacturer's instructions (Technical Bulletin No. 122: Promega, Madison, WI). Granulosa cells were collected from fractions 3 and 4 and cultured for 2 or $48 \mathrm{~h}$ with $0,12.5,25$ or $50 \mathrm{ng}$ ovine $\mathrm{FSH}(\mathrm{S}-17) \mathrm{ml}^{-1}$ in the presence $\left(0.1 \mathrm{mg} \mathrm{ml}^{-1}\right)$ or absence of 8-bromo-cAMP (Sigma Chemical Co.). After culture, the granulosa cells were fixed and the area of 100 granulosa cells from each treatment determined as previously described. This experiment was repeated three times.

\section{Statistical analyses}

When appropriate, the data were analysed by either a two-way or one-way analysis of variance followed by Student-
Newman-Keuls multiple-range test. Only $P$ values $\leq 0.05$ were considered to be significant.

\section{Results}

\section{Characterization of granulosa cells isolated by Percoll gradient centrifugation}

Granulosa cells, isolated from the follicles of eCG-primed immature rat ovaries, were heterogeneous with regard to cell area. Two types of granulosa cells were observed. Small granulosa cells had an average area of $44 \pm I \mu \mathrm{m}^{2}$ (7.5 $\pm 0.2 \mu \mathrm{m}$ diameter), while large granulosa cells had an average area of $97 \pm 2 \mu \mathrm{m}^{2}$ (11.1 $\pm 0.2 \mu \mathrm{m}$ diameter). Granulosa cells were separated into 12 fractions after centrifugation through a $15-45 \%$ Percoll gradient. Most $(\approx 80 \%)$ of the granulosa cells were collected in fractions 6-8 (Fig. Ia). Fractions 1 and 2 contained mainly debris and pyknotic nuclei, while fractions 9-12 possessed very few cells. Fractions 3 and 4 were composed mainly of small granulosa cells. These two fractions typically possessed $70-80 \%$ small cells. Fraction 5 usually contained a high percentage of small granulosa cells but the proportion of small and large granulosa cells varied with each isolation procedure. The average area of granulosa cells within fractions $6-8$ was $79 \pm 2 \mu \mathrm{m}^{2}$ ( $10.0 \pm 0.3 \mu \mathrm{m}$ diameter) (Fig. 1b) with $\approx 60 \%$ of the cells within fractions $6-8$ considered to be large (Fig. 1c). After Percoll gradient centrifugation, the average viability was $89 \pm 2 \%$ for each fraction. These results confirm published results in which rat granulosa cells of different sizes were separated using Percoll gradients (Rao et al., 1991a; Sanbuissho et al., 1993).

A higher rate of oestradiol secretion was observed for granulosa cells isolated in fractions 6 and 7 compared with fractions 3-5 ( $P<0.05$; Fig. $2 \mathrm{a}$ ). This enhanced rate of secretion of oestradiol was correlated with an increase in the percentage of granulosa cells that expressed aromatase, and the relative amount of aromatase protein expressed per cell $(P<0.05$; Fig. 2b).

A comparison of all aromatase-stained cells revealed that only a few small granulosa cells expressed aromatase and at low levels. Aromatase activity of granulosa cells that were $\geq 73 \mu \mathrm{m}^{2}$ was twice that of smaller cells. The relative amount of aromatase expression continued to increase with increasing granulosa cell size, reaching a threefold increase for granulosa cells $\geq 97 \mu^{2}$ (Fig. 3). When aromatase expression is expressed per cellular area, aromatase staining still increased twofold (data not shown). However, not all large granulosa cells expressed aromatase.

The capacity of granulosa cells to undergo mitosis was assessed by exposing cells from the different fractions to insulin in the presence of testosterone. These studies demonstrated that $30-50 \%$ of the granulosa cells in fractions 3 and 5 underwent mitosis in response to insulin within $24 \mathrm{~h}$. The percentage of granulosa cells undergoing mitosis in fractions 7 and 9 was reduced to $\leq 10 \%$ (Fig. 4). Direct observations of cells before and after insulin treatment revealed that the large granulosa cells never divided, while small granulosa cells were observed to undergo cell division (as evidenced by the appearance of two small granulosa cells in a location in which there was only one small granulosa cell prior to insulin 
exposure). Thus, the $10 \%$ increase in the number of cells in fractions 7 and 9 was due to the presence of small granulosa cells.

Since insulin and insulin-like growth factor I are associated with enhanced granulosa cell steroidogenesis (Adashi et al., 1991), it is possible that insulin could stimulate mitoses in the small granulosa cells and oestradiol secretion from the larger
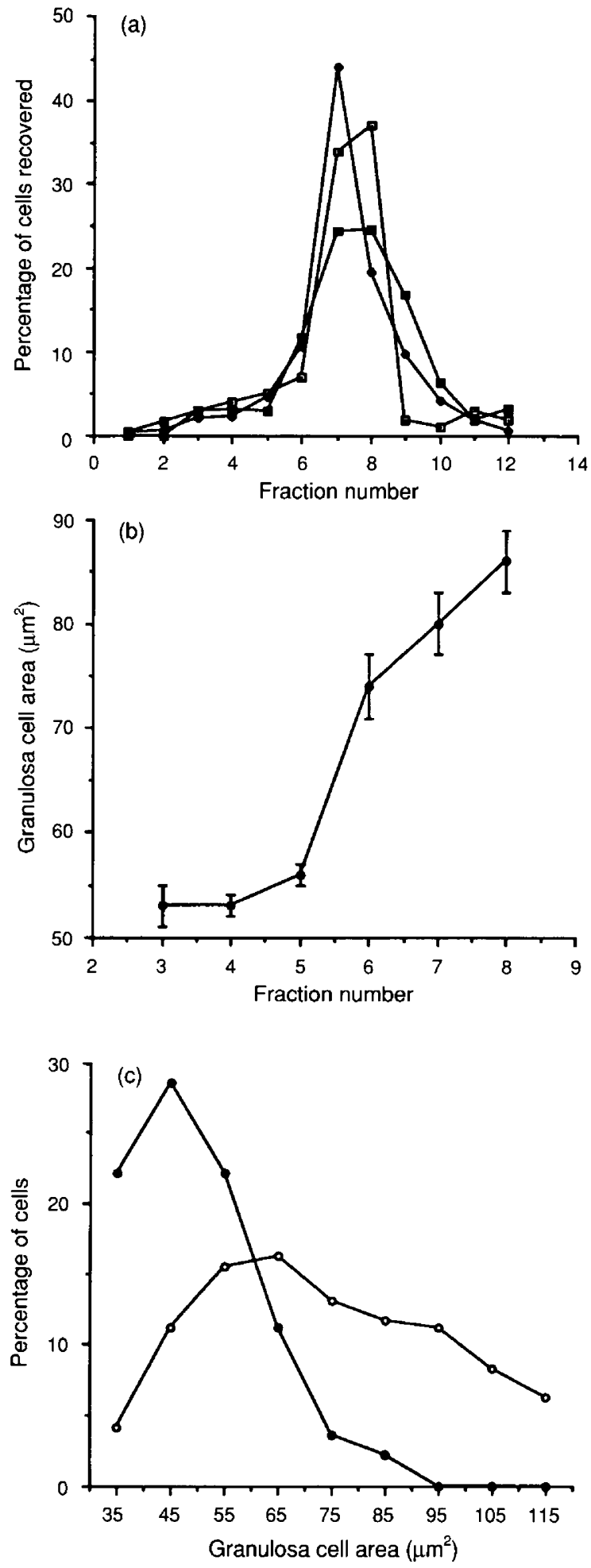

granulosa cells. This hypothesis was tested by culturing small (fractions 3 and 4) and large granulosa cells (fractions 6-8) with testosterone in the absence (control) or presence of insulin. After $24 \mathrm{~h}$, insulin stimulated an increase in the number of small $(P<0.05)$ but not large granulosa cells (Fig. 5a). However, insulin did not enhance oestradiol secretion over basal values for either small or large granulosa cells $(P>0.05)$ (Fig. 5b).

\section{Follicular development and changes in granulosa cell size distribution}

Granulosa cells isolated from immature rat ovaries showed a unimodal distribution with a mode of $50 \mu \mathrm{m}^{2}$. This distribution was observed for the granulosa cells isolated from all sizes of follicles within the immature rat ovary and always showed a slight skew to the right. Treatment with eCG markedly changed the granulosa cell area distribution by increasing the degree of skewness. For the smaller follicles $(73-380 \mu \mathrm{m}$ diameter), the mode was still $50 \mu \mathrm{m}^{2}$ but the percentage of granulosa cells of this area was reduced from $35 \%$ for follicles of immature rats to $17 \%$ for the small follicles of eCG-treated rats. This shift in distribution of granulosa cell area was more pronounced for follicles $\geq 380 \mu \mathrm{m}$ in diameter within eCG-treated rats (Fig. 6).

\section{Effect of FSH and 8-bromo-cAMP on granulosa cell area in vitro}

When small granulosa cells were cultured in the absence of any stimuli, they deteriorated and were not observed after $48 \mathrm{~h}$. In the presence of 8-bromo-cAMP, these cells survived with their area increasing in comparison with the $2 \mathrm{~h}$ controls $(P \leq 0.05)$. FSH, in the presence of 8 -bromo-cAMP, induced a dose-dependent increase in granulosa cell area compared with the 8-bromo-cAMP treatment $(P \leq 0.05)$ (Fig. 7).

\section{Discussion}

The results of the granulosa cell isolation study confirm that ovarian follicles are composed of small and large granulosa cells and that these cells have different functional capacities (Rao et al., 1991a, b; Sanbuissho et al., 1993). The large granulosa cells, isolated in fractions 6-8, are steroidogenic, while the small granulosa cells, collected in fractions 3 and 4 , are less steroidogenic and capable of undergoing insulin-induced mitosis. These findings could be interpreted in at least two

Fig. 1. Separation of granulosa cells isolated from equine chorionic gonadotrophin-treated immature rats using a $15-45 \%$ Percoll gradient. The percentage of cells recovered from each fraction in three representative isolation procedures is shown in (a). The average area \pm SEM of 100 cells isolated from each fraction is presented in (b). Although the cells were large, the areas for cells isolated in fractions 9-12 are not shown, since they comprise a very small percentage of the total cells and were not used in any studies. On the basis of average area, granulosa cells within fractions 3 and 4 and 6-8 were collected to form small and large pools, respectively. As can be seen in (c), about $80 \%$ of the granulosa cells in the small pool ( $\bullet$ ) are $\leq 75 \mu \mathrm{m}^{2}$, while about $60 \%$ of the cells in the large pool () are $\geq 75 \mu \mathrm{m}^{2}$. 

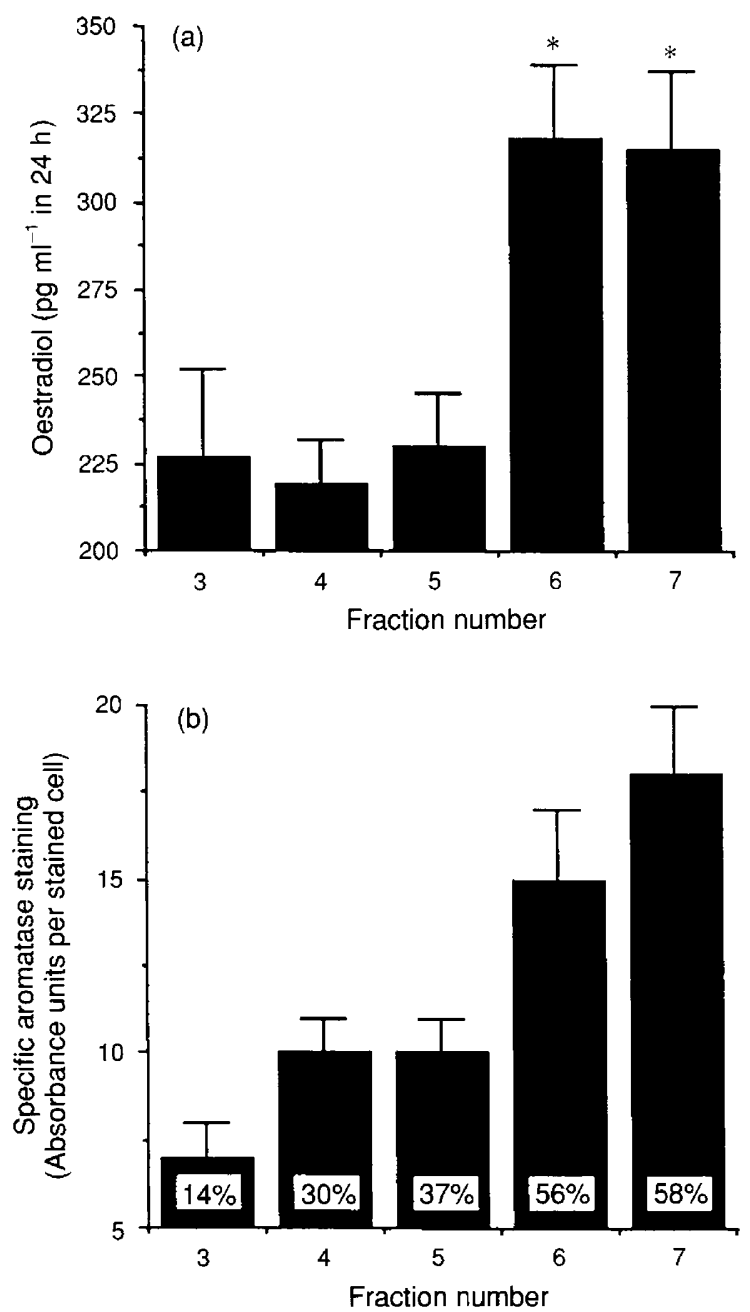

Fig. 2. Steroidogenic characteristics of granulosa cells isolated from equine chorionic gonadotrophin-treated immature rats. (a) Oestradiol concentration from granulosa cells of each fraction was determined by radioimmunoassay after $24 \mathrm{~h}$ of culture. Results are expressed as means \pm SEM of replicate cultures $(n=4)$ of a typical experiment. (b) Aromatase was localized by immunocytochemistry using the antiaromatase antibody generously provided by $\mathrm{Y}$. Owasa (Medical Foundation of Buffalo). The amount of aromatase per stained cell was estimated using imaging densitometry. The percentage of granulosa cells specifically stained for aromatase is shown at the base of each bar.

ways. First, both small and large granulosa cells could be members of a single granulosa cell population with the variation in cell size due to the well-documented changes associated with mitosis (Baserga, 1985). For example, after cytokinesis, cells enlarge until they can undergo another cell division. When exposed to the appropriate mitogen, they leave the Go-G1 stage of the cell cycle, subsequently enter the $S$ and G2-M phases and then undergo cytokinesis. As a result of cytokinesis, their size is reduced by half (Baserga, 1985). Thus, the twofold difference in granulosa cell size could be explained by the changes associated with cell division. If this were the case, then small granulosa cells would not be observed in the $S$ and G2-M phases of the cell cycle. However, small granulosa cells are observed in all stages of the cell cycle (Rao et al.,

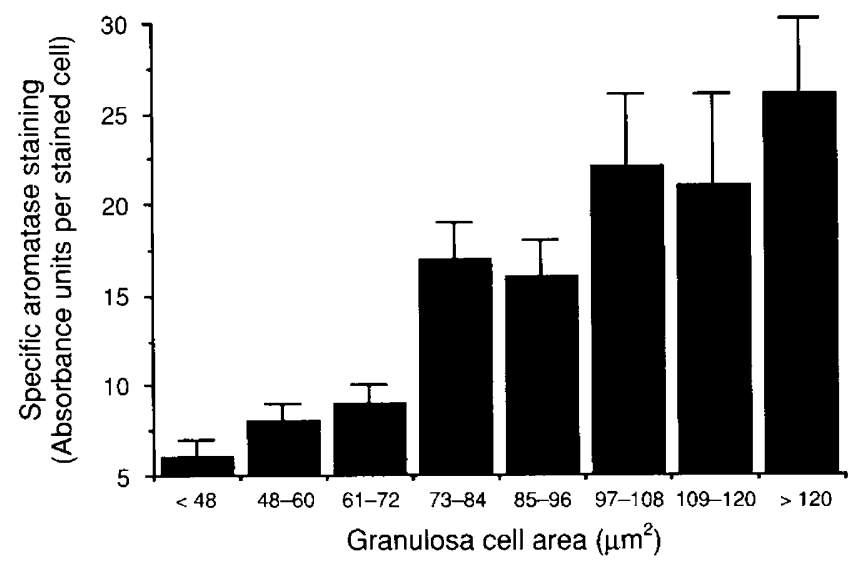

Fig. 3. The effect of rat granulosa cell area on the relative amount of aromatase expressed per cell. Data shown in this figure were obtained by evaluating all cells that showed positive staining for aromatase, independent of the fraction in which they were isolated. Note that for those cells that expressed aromatase, the relative amount of aromatase expression increases with increasing cell area.

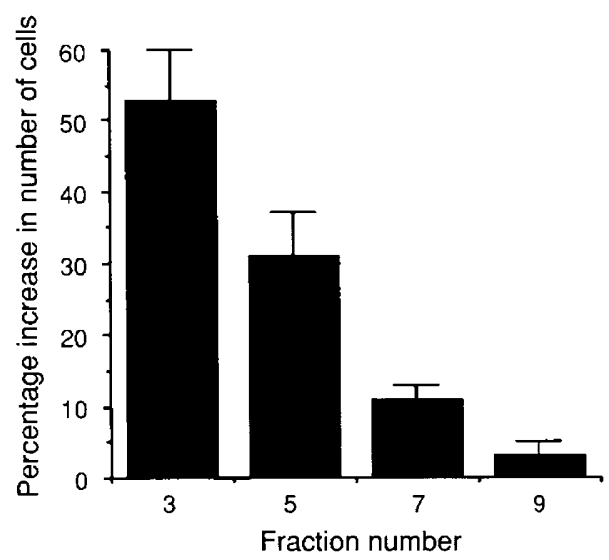

Fig. 4. Mitotic potential of granulosa cells collected from equine chorionic gonadotrophin-treated immature rats. The cells from every other fraction were cultured in the presence of testosterone and insulin. After $24 \mathrm{~h}$ the percentage increase in number of cells was assessed using an in situ counting protocol. The values are expressed as means \pm SEM with each treatment replicated five or more times per experiment. A minimum of 100 cells per treatment was observed in each experiment and the experimental series was repeated twice. Similar results were obtained for each replicate experiment.

1991b). This strongly supports the alternative concept that there are two populations of granulosa cell, which differ in terms of both size and function. This leads to the question of whether it is possible for small granulosa cells to develop into large granulosa cells.

This question was addressed by culturing small granulosa cells under conditions known to promote aromatase activity and oestrogen secretion (i.e., with FSH and 8-bromo-cAMP) (Richards and Hedin, 1988). The data from this study demonstrate that over a $48 \mathrm{~h}$ culture period, FSH and cAMP induce differentiation of small granulosa cells to large granulosa cells. This FSH- and cAMP-induced increase in granulosa cell size is associated with enhanced aromatase expression (J. Peluso, unpublished). It is important to appreciate that not all large 

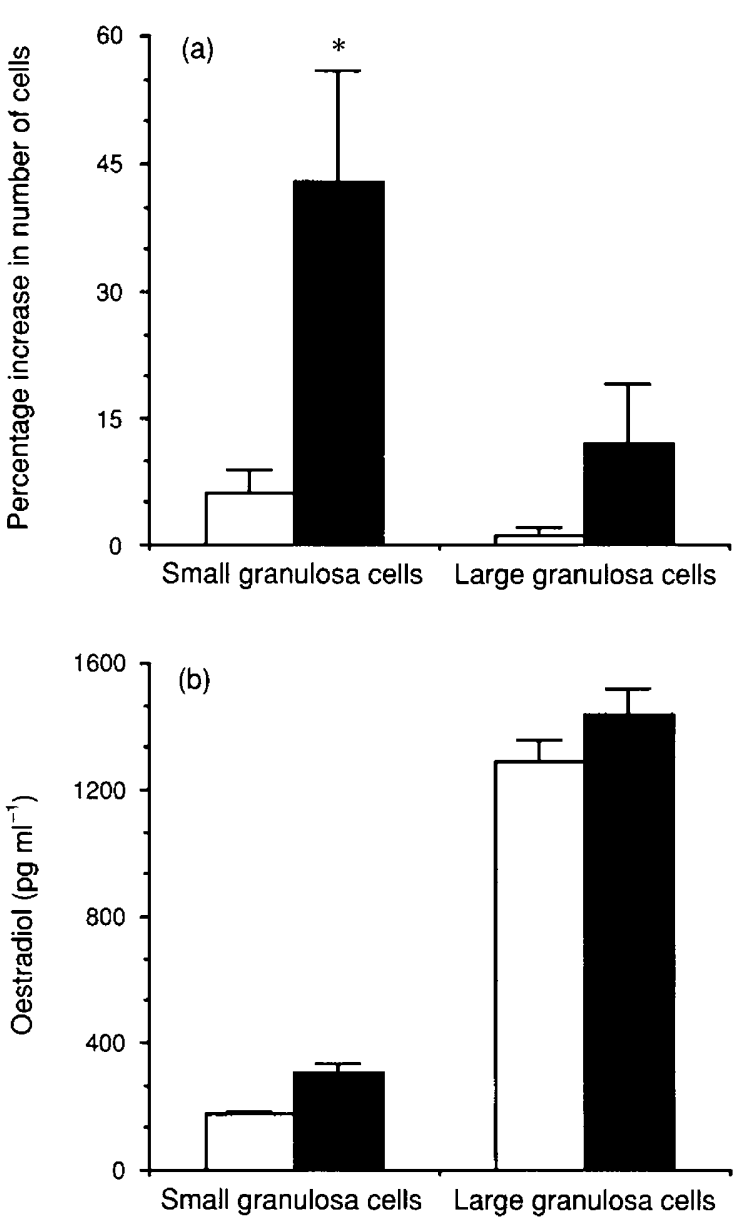

Fig. 5. The effect of insulin treatment on mitosis and secretion of oestradiol from small and large rat granulosa cells isolated after equine chorionic gonadotrophin treatment. The results are shown as means \pm SEM with each treatment conducted within a single experiment. $(\square)$ control values; ( $\square$ ) insulin values. *Significant difference from control $(P<0.05)$. A minimum of 100 cells per treatment was observed in each experiment and the entire experimental series was repeated twice. Similar results were obtained for replicate experiments.

granulosa cells express aromatase and, for those that do, the amount of aromatase expression gradually increases with increasing area. Thus, aromatase expression is not an all-ornone event, but rather occurs as a graded response, positively correlated with cell area. This supports the suggestion that granulosa cell differentiation is a complex process that occurs over 2-3 days and involves the precise temporal expression of a sequence of several genes, and that ultimately alters morphology and steroidogenic function of granulosa cells (Amsterdam et al., 1989; Richards and Hedin, 1988).

In contrast to the gradual increase in aromatase expression and cell area that characterize granulosa cell differentiation, mitotic potential appears to be an all-or-none phenomenon; only small granulosa cells can undergo mitosis in response to insulin. Since (i) not all large granulosa cells expressed aromatase and (ii) large granulosa cells were never observed to undergo insulin-induced mitosis, the loss of mitotic potential appears directly related to an increase in granulosa cell area and not to the expression of aromatase itself. This observation

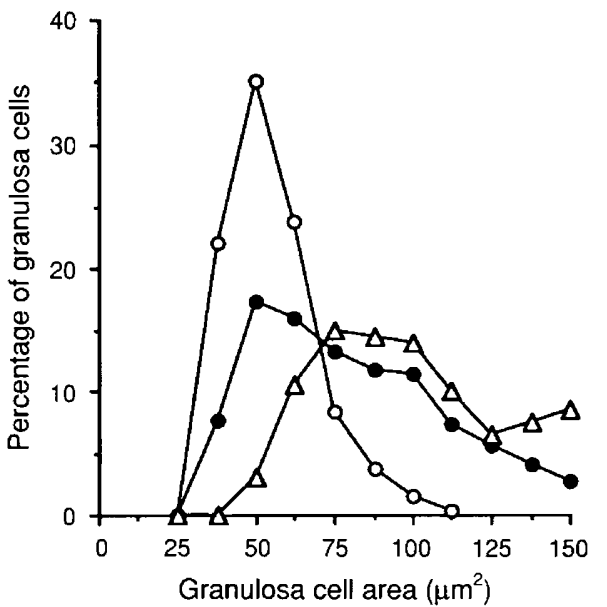

Fig. 6. The effect of equine chorionic gonadotrophin treatment on the rat granulosa cell area distribution within follicles of different size. The area of 100 granulosa cells from each size of follicle was determined. Since the area distribution was identical for all follicles isolated from immature ovaries, these data were pooled (o). The cell area distribution of follicles isolated after equine chorionic gonadotrophin treatment differed from those of immature rat ovaries in that the cell area distributions of both follicles within the 73-380 $\mu \mathrm{m}$ diameter range $(\bullet)$ and the larger follicles ( $\geq 380 \mu \mathrm{m}$ diameter: $\Delta$ ) were skewed to the right.

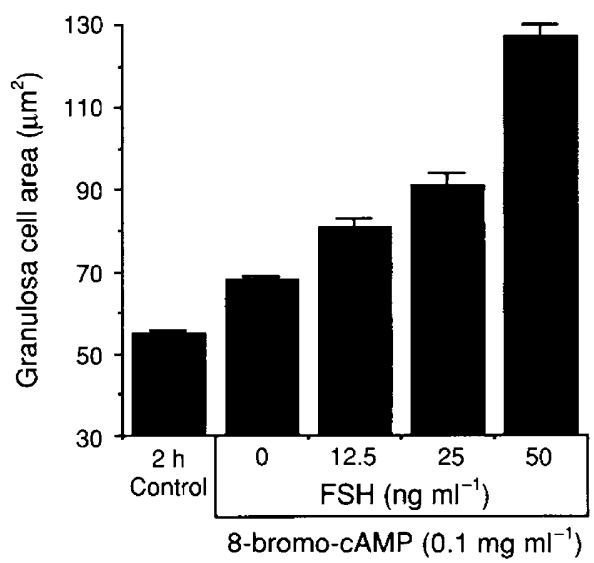

Fig. 7. The effect of exposure to FSH and 8-bromo-cAMP in vitro on rat granulosa cell area. Cells from fractions 3 and 4 were cultured for $2 \mathrm{~h}$ or $48 \mathrm{~h}$ on ProNectin-coated Lab-tek slides and then prepared for area measurements. One hundred cells were assessed for each group. Results are means \pm SEM for a typical experiment. This experiment was repeated three times.

suggests that once a granulosa cell starts to enlarge, but before the maximal expression of aromatase, it loses its ability to undergo insulin-induced mitosis.

Although it is possible that large granulosa cells are terminally differentiated and have lost all mitogenic potential, this conclusion cannot be drawn with certainty, since there may be redundant mitogenic pathways that are not stimulated by insulin or insulin-like growth factor I. For example, transforming growth factor $\beta$ (TGF- $\beta$ ) in the presence of $5 \mathrm{ng} \mathrm{FSH} \mathrm{mi}{ }^{-1}$ stimulates DNA synthesis of rat granulosa cells (Dorrington et al., 1990). Similarly, simultaneous exposure to both TGF- $\beta$ 
and epidermal growth factor (EGF) stimulates DNA synthesis of rat granulosa cells (Bendell and Dorrington, 1990). These gonadotrophin/growth factor combinations may be able to stimulate mitogenic pathways in large granulosa cells but this remains to be tested. The contention that large granulosa cells may be capable of mitosis is supported by the observation that the same percentage of small and large granulosa cells are observed in the G2-M stage of the cell cycle (Rao et al., 1991b).

The present study clearly demonstrates that only a select population of granulosa cells can undergo insulin-dependent mitosis. Our previous work has shown that insulin simultaneously suppresses follicular oestradiol production and increases $\left[{ }^{3} \mathrm{H}\right]$ thymidine incorporation by granulosa cells of follicles within perifused immature rat ovaries (Peluso et al., 1991). This observation led us to propose that granulosa cells secreting oestradiol can divide but their ability to secrete oestradiol is temporarily inhibited during insulin-induced mitosis. The present data refute this hypothesis. Rather, it appears that insulin stimulates a population of small granulosa cells within the perifused immature rat ovary to incorporate $\left[{ }^{3} \mathrm{H}\right]$ thymidine and divide. The mechanism responsible for the insulinmediated reduction of follicular oestradiol secretion is unknown. The results of the isolated granulosa cell culture studies suggest that it is unlikely that insulin alone has a direct, adverse effect on oestradiol secretion within $24 \mathrm{~h}$. It is possible that insulin may interact with unknown intraovarian factors to initially reduce oestradiol secretion, thereby accounting for the anti-steroidogenic action of insulin in perifusion culture (Peluso et al., 1991).

The types of granulosa cell within an ovarian follicle change with increasing follicular size and maturation. Small antral follicles are the most abundant follicles within the immature (22-25 day old) rat ovary (Peluso, 1988). These follicles are mainly composed of small, mitotically competent granulosa cells. As they grow in response to gonadotrophin stimulation, the number of small, mitotically competent granulosa cells decreases and the number of large, aromatase-expressing granulosa cells increases (present study; Sanbuissho et al., 1993). This change in the granulosa cell composition could be due to either a rapid proliferation of large cells or to the differentiation of small cells into large cells. As previously discussed, large granulosa cells are unlikely to be able to divide and gonadotrophins can induce the differentiation of small granulosa cells into large granulosa cells. These observations suggest that, as follicles develop under the influence of gonadotrophin stimulation, small granulosa cells differentiate into large granulosa cells that have a reduced mitogenic capability. This change in granulosa cell populations could account for (i) the slower growth rate of larger follicles compared with small antral follicles (Hirshfield, 1991); Pedersen, 1972) and (ii) the inverse relationship observed between oestradiol secretion and granulosa cell DNA synthesis (Frishman et al., 1992; Monniaux, 1987).

The authors thank $Y$. Osawa of the Medical Foundation of Buffalo Research Institute, for providing the rabbit anti-aromatase antibody used in this study. They thank also the NIAMDD for the gift of the ovine FSH and D. Shapiro for aiding in the image analysis. This work was supported in part by NIH Grant 1-R55-HD27578-01A2.

\section{References}

Adashi EY, Resnick CE, Hernandez ER, Hurwitz A, Roberts CT and Leroith D (1991) Insulin-like growth factor I as an intraovarian regulator: basic and clinical implications Annals of the New York Academy of Science 626 161-168

Amsterdam A, Rotmensch S and Ben-Ze'ev A (1989) Coordinated regulation of morphological and biochemical differentiation in a steroidogenic cell: the granulosa cell model Trends in Biological Science 14 376-382

Baserga R (1985) The Biology of Cell Reproduction. Harvard University Press, Cambridge, MA

Bendell J and Dorrington J (1990) Epidermal growth factor influences growth and differentiation of rat granulosa cells Endocrinology 127 533-541

Bley M, Simon J, Saragueta P and Baranao J (1991) Hormonal regulation of rat granulosa cell deoxyribonucleic acid synthesis: effects of estrogens Biology of Reproduction 44 880-888

Bucana C, Saiki I and Nayar R (1986) Uptake and accumulation of the vital dye hydroethidine in neoplastic cells Journal of Histochemistry and Cytochemistry 34 1109-1115

Dorrington J, Chuma A and Bendell J (1990) Transforming growth factor $\beta$ and follicle-stimulating hormone promote rat granulosa cell proliferation Endocrinology 123 353-359

Frishman G, Luciano A and Peluso J (1992) Effect of the ratio of folliclestimulating hormone to luteinizing hormone on rat granulosa cell proliferation and oestradiol-17 $\beta$ secretion Human Reproduction 7 1073-1078

Greenwald G and Terranova P (1988) Follicular selection and its control. In The Physiology of Reproduction pp 387-446 Eds E Knobil, LL Ewing, GS Greenwald, CL Markert and DW Pfaff. Raven Press, New York

Hartshorne G (1990) Subpopulations of granulosa cells within the human ovarian follicle Journal of Reproduction and Fertility $89773-782$

Hirshfield A (1991) Development of follicles in the mammalian ovary International Reviews of Cylology 124 43-10I

Ishimura K, Yoshinaga-Hirabayashi T, Tsuri H, Fujita H and Osawa Y (1989) Further immunocytochemical study on the localization of aromatase in the ovary of rats and mice Histochemistry $90413-416$

Monniaux D (1987) Short-term effects of FSH in vitro on granulosa cells of individual sheep follicles Journal of Reproduction and Fertility 79 505-515

Pedersen T (1972) Follicle growth in the mouse ovary. In Oogenesis pp 361-376 Eds JD Biggers and AW Schuetz. Butterworths, Baltimore.

Peluso J (1988) Effect of the peripubertal pattern of LH and FSH secretion on in vitro oestradiol- $17 \beta$ secretion and follicular growth within the juvenile rat ovaries Journal of Reproduction and Fertility 84 239-245

Peluso J, Delidow B, Lynch J and White B (1991) Follicle-stimulating hormone and insulin regulation of $17 \beta$-estradiol secretion and granulosa cell proliferation within immature rat ovaries maintained in perifusion culture Endocrinology 128 191-196

Peluso JJ, Pappalardo A and White BA (1993) Control of rat granulosa cell mitosis by phorbol ester-, cyclic AMP-, and estradiol-17beta-dependent pathways Biology of Reproduction 49 416-422

Rao IM, Mills TM, Anderson E and Mahesh VB (1991a) Heterogeneity in granulosa cells of developing rat follicles Anatomical Record 229 177-185

Rao IM, Alsbrook W, Conway B, Martinez J, Beck J and Pantazis C (1991b) Flow cytometric analysis of granulosa cells from developing rat follicles journal of Reproduction and Fertility 91 521-530

Richards J and Hedin L (1988) Molecular aspects of hormone action in ovarian follicular development, ovulation and luteinization Annual Review of Physiology $50441-463$

Roy S and Greenwald G (1988) In vitro effects of follicle-stimulating hormone, luteinizing hormone, and prolactin on follicular deoxyribonucleic acid synthesis in the hamster Endocrinology 122 952-958

Sanbuissho A, Lee GY and Anderson E (1993) Functional and ultrastructural characteristics of two types of rat granulosa cell cultured in the presence of FSH or transforming growth factor alpha (TGF-alpha) Journal of Reproduction and Fertility 98 367-376

Tamura T, Kitawaki J, Yamamoto T, Osawa Y, Kominami S and Takemori S (1992) Immunohistochemical localization of 17alpha-hydroxylase/C17-20 lyase and aromatase cytochrome P-450 in the human ovary during the menstrual cycle Journal of Endocrinology 135 589-595

Vacca-Galloway L (1985) Differential immunostaining for substance $P$ in Huntington's diseased and normal spinal cord: significance of serial (optimal, supra-optimal and end-point) dilutions of primary anti-serum in comparing biological specimens Histochemistry 83 561-569 